\title{
ENERGY ANALYSIS IN RESIDENTIAL BUILDING FOR INSULATION ROOF MATERIAL USING BUILDING INFORMATION MODELLING. \\ DOI:10.36909/jer.ACMM.16303
}

\author{
Prerna sharma $^{1}$ and V. R. Prasath kumar ${ }^{2 *}$ \\ ${ }^{1}$ Research scholar, Department of Civil Engineering, Faculty of Engineering and \\ Technology, SRM Institute of Science and Technology, Kattankulathur - 603203, Tamil \\ Nadu, India, \\ ${ }^{2 *}$ Assistant Professor, Department of Civil Engineering, Faculty of Engineering and \\ Technology, SRM Institute of Science and Technology, Kattankulathur - 603203, Tamil \\ Nadu, India,prasathv@srmist.edu.in
}

\begin{abstract}
Energy efficient is becoming a significant subject to investigate within the Architecture Engineering and Construction (AEC), as a result of the expanding heating and energy usage problem. Lack of interoperability has been identified as a hurdle to increased efficiency in the AEC. In order to fulfil the expanding demands around the world, the energy analysis must be incorporated into the building's planning section. Predicting a building's energy use and establishing an energy-saving life and style are both required. To conduct an energy study of a $\mathrm{G}+3$ residential structure, the article uses Autodesk (BIM) capabilities. The goals of this project are to find BIM energy analysis into calculating a building's energy consumption, as well as to conclude the life cycle cost and energy cost over time, in same building. This study's primary focus is on roof materials and alternatives accomplished with the use of Autodesk Revit software and Green Building Studio, a cloud-based energy analysis application.
\end{abstract}

Keywords: Energy simulation analysis, Residential building, Energy usage, Building Information Modeling, Green Building Studio. 


\section{INTRODUCTION}

The construction sector has to focus on the design and construction of structures. Green building has now become a symbol of the construction industry's commitment to long-term economic, environmental, and social well-being (Hedayati 2016). Residential building energy use and $\mathrm{CO}_{2}$ emissions are influenced by a number of factors. The first one is the energy mix as well as the other is the structure's design and current electromechanical technology (Vogiatzi et al. 2018). The Building Life Cycle which begins with design and continues through conception, occupation and destruction, defines the whole life cycle of a structure. This involves the incorporation of long-term energy-efficient architecture into all structures. As a result the majority of construction companies use sophisticated energy modeling and analysis tools (Venkataraman and Kannan 2013). Temperature has a big influence on how well a building works and how much energy it uses. The goals of a climatically responsive sustainable building design are to reduce energy consumption, conserve natural resources and create comfortable healthy and long-lasting living spaces. (Taleghani et.al2010). An crucial 3D model for existing structures can be generated using BIM, allowing for the quick completion of an underlying vitality assessment and examination of the method for structure maintenance. (Ashik Moulana and Syed Abdul Rahman 2017).

The roof is a crucial component of the structure. In selecting a roofing material, all technical aspects that define the quality of the materials that were used as well as the cost of the same must be considered. Ceramic and cement tiles as well as shingles are examples of heavy roofing, while sheet, roofing tar and plastics are examples of light roofing. Styles of roofing have advantages and disadvantages (Radziszewska-Zielina 2014, Banihashemi, Ding, and Wang 2015). Various studies have recorded and continue to emphasize the frequently considerable disparities found when comparing the anticipated energy usage outputs of these modeling techniques to the observed data energy usage in residential spaces since the early stages of energy simulation and modeling (Norford et al. 1994 and Agami Reddy 2006). In recent years, system performance and building component thermal properties have steadily improved resulting in a more comfortable interior atmosphere while consuming less energy for space heating (Hamilton et.al 2016). Several research have connected improved insulation and more energy-efficient heating and ventilation systems to lower energy use (Caldera, Corgnati et.al 2008, Catalina, Virgon et.al 2008). A building requires a specific quantity of energy to run, maintain user comfort and function (De Gracia and Cabeza 2015). The calculation of required energy demand is strongly reliant on energy balance. Energy losses 
from the building envelope such as transmission and ventilation losses account for the required energy (Basack and Sarkar 2019). The use of as much natural energy as feasible could lead to a reduction in the amount of fuel needed by the structure. Lighting, ventilation and the operation of building systems all require additional energy input (Balali et.al 2020). The use of passive measures in energy consumption optimization has been touted as the most successful and cost-effective way for reducing energy resource manipulation through building demands, but it is highly reliant on both climate and building characteristics (Gong et al. 2019).

BIM allows to test analyze and improve a building's design over time, resulting in a more sustainable design, it is referred to as a Building Performance Analysis (BPA). The use of BIM electricity evaluation technology can help predict occupant thermal comfort and a building's overall electricity performance (Santos et.al 2017)(Gerrish et al. 2017). The building pure mathematics which include the layout and configuration of the area (surfaces and volumes), the orientation of the building information about the material properties used and their thermal characteristics of building components and the practical use of the building to be studied and analyzed are the statistics required for the building energy analysis. Lighting resident and equipment schedules, kind of HVAC system, utility pricing and climate data for the globe where the facility is located (Migilinskas et al. 2013), (Ji and AbouRizk 2018).

In this study, a building model is constructed that can be used to conduct a vitality evaluation, allowing users to envision and re-enact the construction process, look and cost. BIM allows for better more informed analysis resulting in increased financial and budgetary benefits for energy productivity projects.

\section{SOFTWARE ANALYSIS}

The purpose of energy analysis is to gather and provide data for decision-making at various stages of the construction, design and use of a building. The entire structure is considered with all of the weather systems operating together. An Autodesk Revit and an Autodesk Green Building Studio assist and examine the performance analysis.

\section{REVIT}

Revit is a full-featured building data modelling program that may be used at any point during the 3D modelling process. To build 3D models, the Autodesk Revit program use Walls, roofs, windows and floors are examples of building elements. Abstract massing capabilities are also available in Revit which use basic forms to represent building form and orientation earlier in the design process. 


\section{GREEN BUILDING STUDIO}

GBS is a web-based simulation engine for assessing the energy efficiency of a building. It is used to fuel the BIM-based energy/sustainability model which runs on the DOE-2 simulation engine (Luziani and Paramita 2019). Revit Autodesk applications that provide complete building energy evaluation capabilities. DOE 2 is a GBS backend that works as a web application displaying the generated data in a legible format. It can evaluate any gbXML file making it compatible with any program which can produce gbXML files..

\section{METHODOLOGY}

Outlining the energy aim is the first step in energy simulation. The intended steps are:

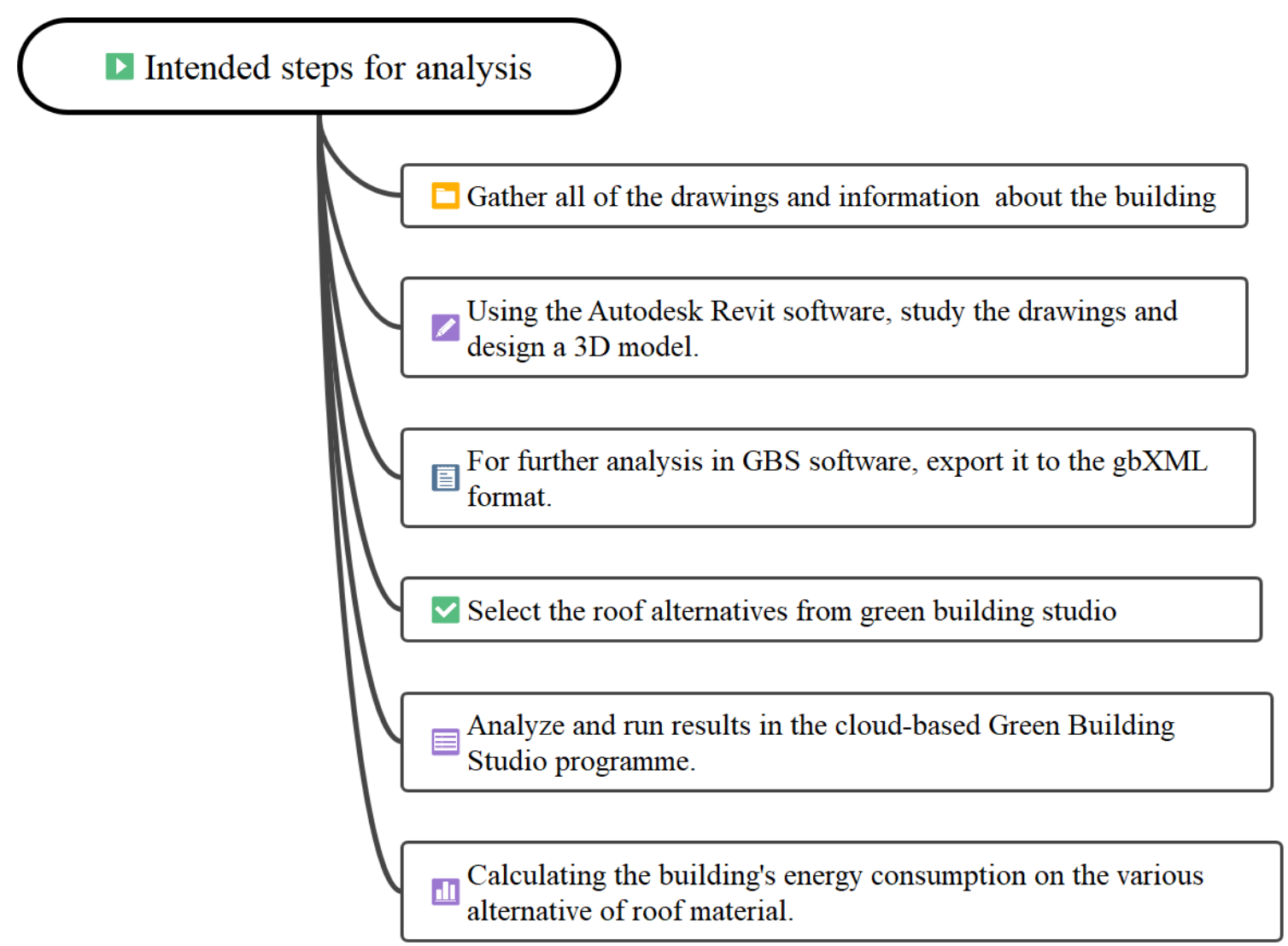

Figure 1 Steps in analysis

\section{CASE STUDY}

The case study is based on an actual residential building project in Sikkim, India. Creating BIM models for analysis within Revit and exporting to GBS for further analysis was part of the process. Table 1 shows the summary of the project: 
Table 1 Details of the residential project

\begin{tabular}{|l|l|}
\hline Project Description & Project Details \\
\hline Building type & Residential Building \\
\hline Schedule & $24 / 7$ facility \\
\hline Project type & Existing building \\
\hline Floor Area & $803 \mathrm{~m}^{2}$ \\
\hline No of Floors & $\mathrm{G}+3$ \\
\hline Location & Gangtok sikkim \\
\hline Climatic condition & Cold \\
\hline
\end{tabular}

The 3D model of the building is shown in the Figure 2. The area tags have been allocated to the rooms generated with the Revit "Room" Tool. Rooms must be created to assist in the conversion of the file to the gbXML format select the type of building, project location, Rooms or Areas in the Building component (if an abstract energy mass model is being generated), Thermal Properties if applicable, then export the file to gbXML.

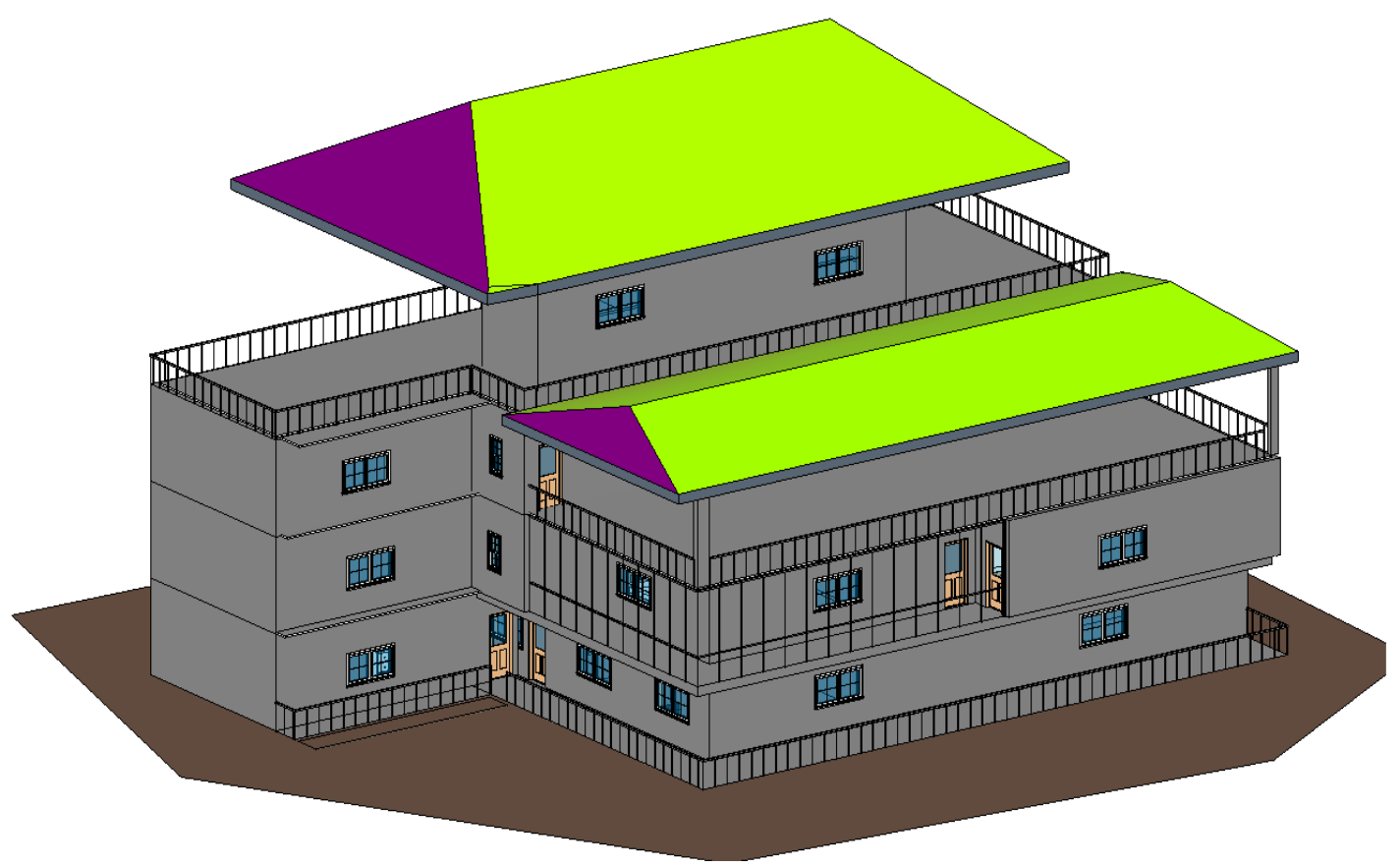

Figure 2 3D model of the building. 


\section{ROOF}

The roof is an important part of any structure and its full collapse renders the structure. When a roofing system fails totally, it is commonly associated with hazards to nearby structures even to the residents living within causing pain. In this study, the roof was installed in Revit as a basic generic wall 12" with a base run analysis performed at the initial stage in GBS. The twenty-three different roof materials available in GBS have been chosen and the simulation options to be run. Table 2 contains information on twenty-three alternatives and their attributes and each roof is denoted by "A-W" as alternative roof.

Table 2 Roof alternatives and its properties.

\begin{tabular}{|l|l|}
\hline SI. No & \multicolumn{1}{|c|}{ Roof Alternatives } \\
\hline A & R60 wood frame roof \\
\hline B & structural ins. Panel (SIP) Roof 10.25in $(260 \mathrm{~mm})$ \\
\hline C & cool roof- R50 continuous ins. over deck \\
\hline D & cool roof- R38 continuous ins. over deck \\
\hline E & structural ins. panel (SIP) Roof 8.25in $(210 \mathrm{~mm})$ \\
\hline F & structural ins. panel (SIP) Roof 6.25in $(165 \mathrm{~mm})$ \\
\hline G & cool roof- R30 continuous ins. over deck \\
\hline H & cool roof- R20 continuous ins. over deck \\
\hline I & cool roof- R15 continuous ins. over deck \\
\hline J & cool roof- R11 continuous ins. over deck \\
\hline K & continuous deck roof with super high insulation \\
\hline L & continuous deck roof with high insulation \\
\hline M & continuous deck roof with code compliant insulation \\
\hline N & continuous deck roof without insulation \\
\hline O & wood frame roof with super high insulation \\
\hline P & wood frame roof with high insulation \\
\hline Q & wood frame roof with code compliant insulation \\
\hline R & wood frame without insulation \\
\hline S & metal frame roof with super high insulation \\
\hline T & metal frame with high insulation \\
\hline W & metal frame without insulation \\
\hline metal frame roof code compliant insulation \\
\hline Metal frame with insulation \\
\hline
\end{tabular}




\section{ROOF INSULATION}

Insulating a building is a smart financial and environmental decision. When insulation is implemented, buildings use less energy for heating, cooling and residents have less thermal variability (Toguyeni et al. 2012). The R-value of a substance is a measurement of its ability to withstand heat transfer from one side to the other. Insulation effectiveness is measured in R-values with a higher number signifying more effective insulation.

\section{COMPARISON AND RESULTS}

These are the outcomes of a cloud-based energy analysis using the GBS software.

\section{ANNUAL ENERGY COST}

The estimated annual utility cost for the entire project's energy and fuel consumption. As illustrated in the figure 3 , the base run is taken as the initial project with the dimensions and data provided. the twenty three other material simulations are conducted $\mathrm{A}-\mathrm{W}$ as mentioned in the above table. It is observed that when the roof is insulated the energy costs can be reduced.

Base run Rs. 2655

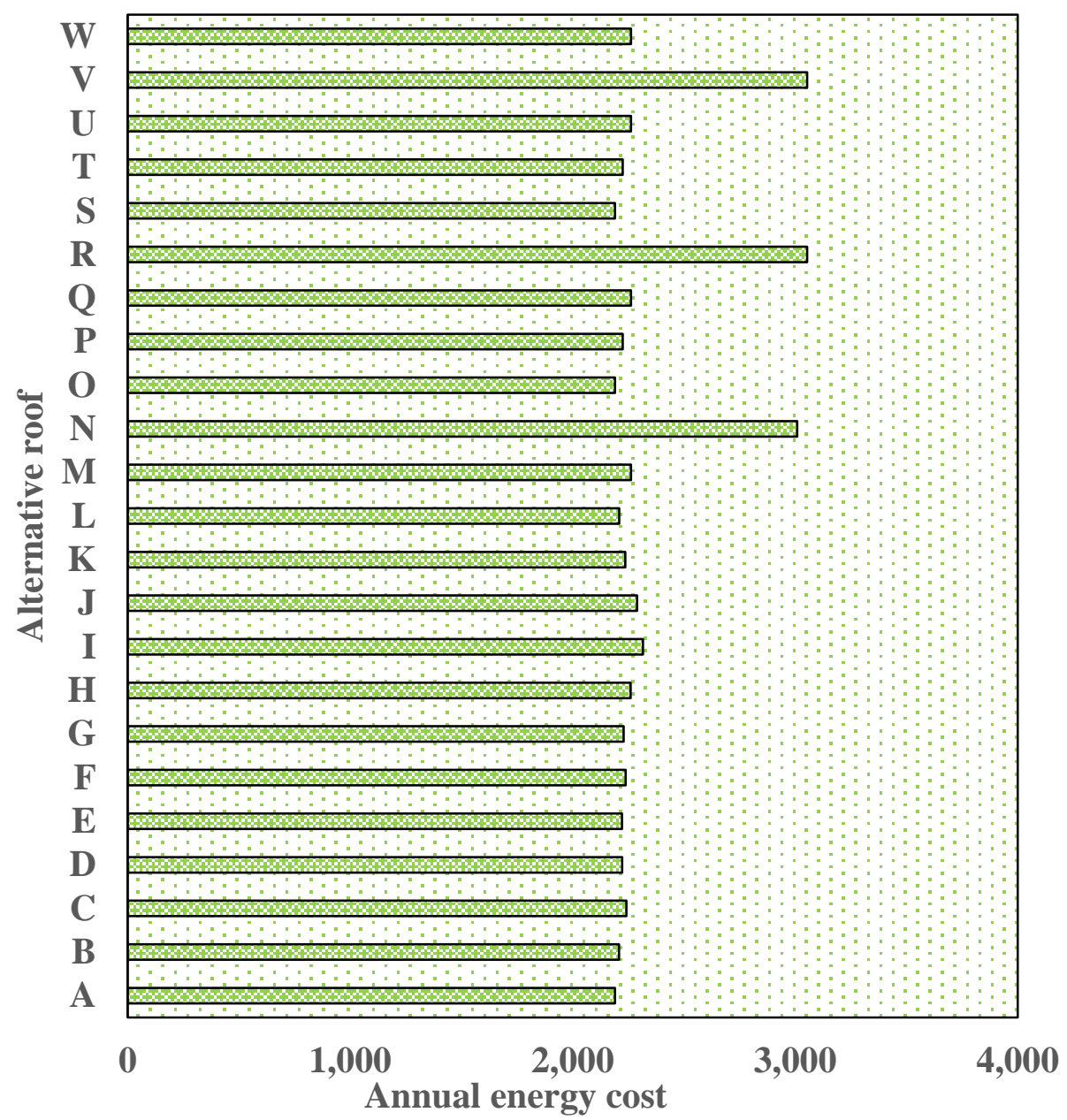

Figure 3 Annual energy cost for roof alternatives 


\section{PROPERTIES OF COMPONENTS}

U-values are used to assess how well insulating elements of a building's fabric perform. The annual energy cost can be reduced by using the alternative material R60 wood frame roof, the properties of other components vary as well. Table 3 summarizes the properties of each element as well as their U-value.

Table 3 Properties of Components and U-value

\begin{tabular}{|l|l|l|}
\hline \multicolumn{1}{|c|}{ Component } & \multicolumn{1}{|c|}{ Properties } & U-Value \\
\hline Roofs & R60 Wood Frame Roof & 0.08 \\
\hline Ceilings & Interior Drop Ceiling Tile & 2.60 \\
\hline Exterior Walls & $\begin{array}{l}\text { R15 Metal Frame Wall R13 Wood Frame } \\
\text { Wall, Wood Shingle }\end{array}$ & 0.33 \\
& & 0.46 \\
\hline Interior Walls & Uninsulated Interior Wall & 2.35 \\
\hline Interior Floors & $\begin{array}{l}\text { Wood Frame Carpeted Floor Interior Drop } \\
\text { Ceiling Tile }\end{array}$ & 1.16 \\
& R2 Default Door (31 doors) & 2.60 \\
\hline Non sliding Doors & & 2.39 \\
\hline
\end{tabular}

\section{ENERGY USAGE}

Energy efficiency refers to utilizing less energy to accomplish the same task or eliminating energy waste. In Figures 4 and 5, it is shown that adopting the R60 wood frame roof as an alternative will lower the building's electric and fuel use.

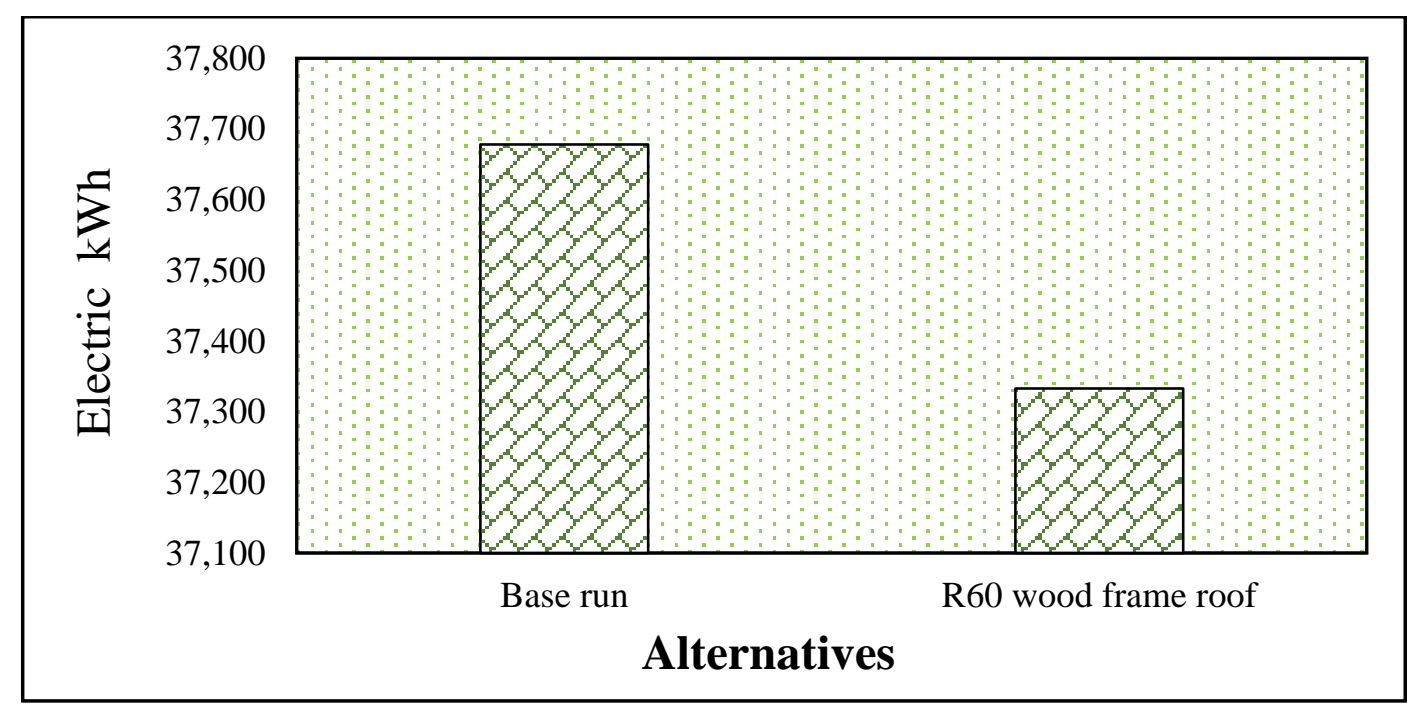

Figure 4 Comparison of Electric use 


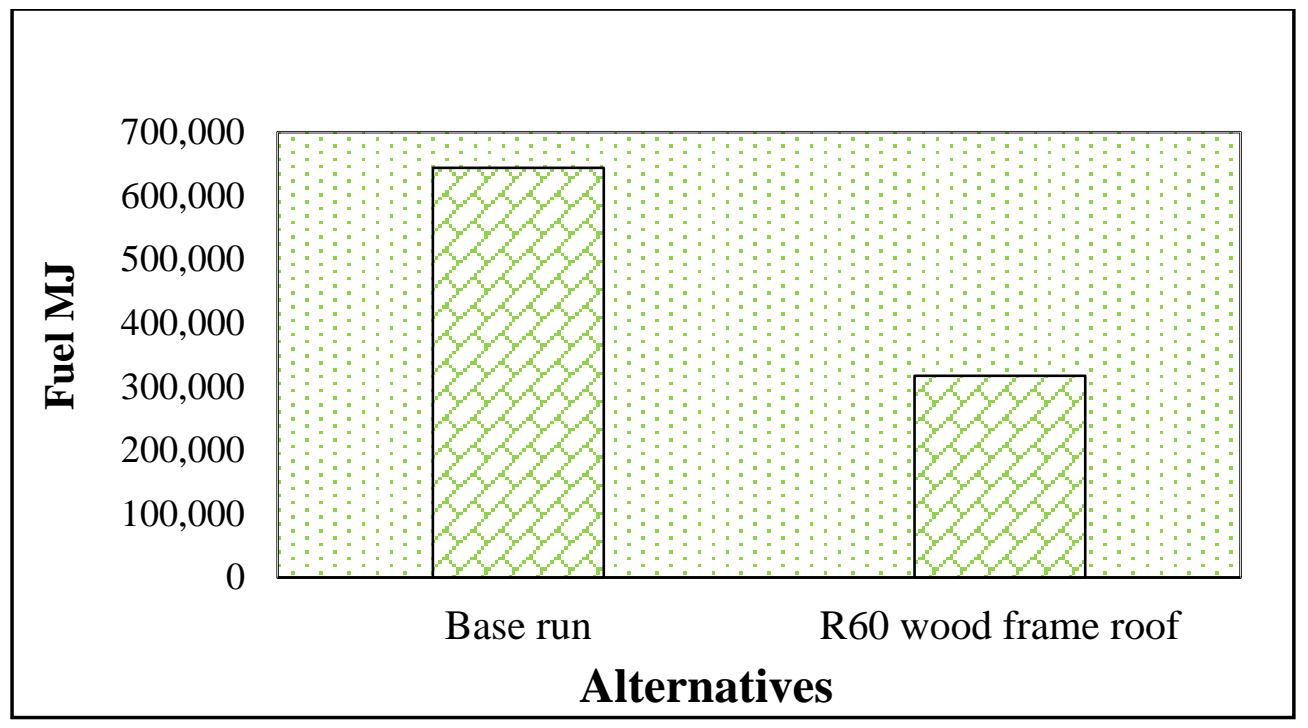

Figure 5 Comparison of Fuel use

\section{ENERGY USE INTENSITY}

The Energy Use Intensity (EUI) of a building is a measure of its energy efficiency. It is calculated by adding up the whole amount of power used by the building's complete gross floor area over the course of a year. Figure 6 shows that adopting R60 wood frame roofs reduces the building's energy use intensity derived by the cloud data computing GBS.

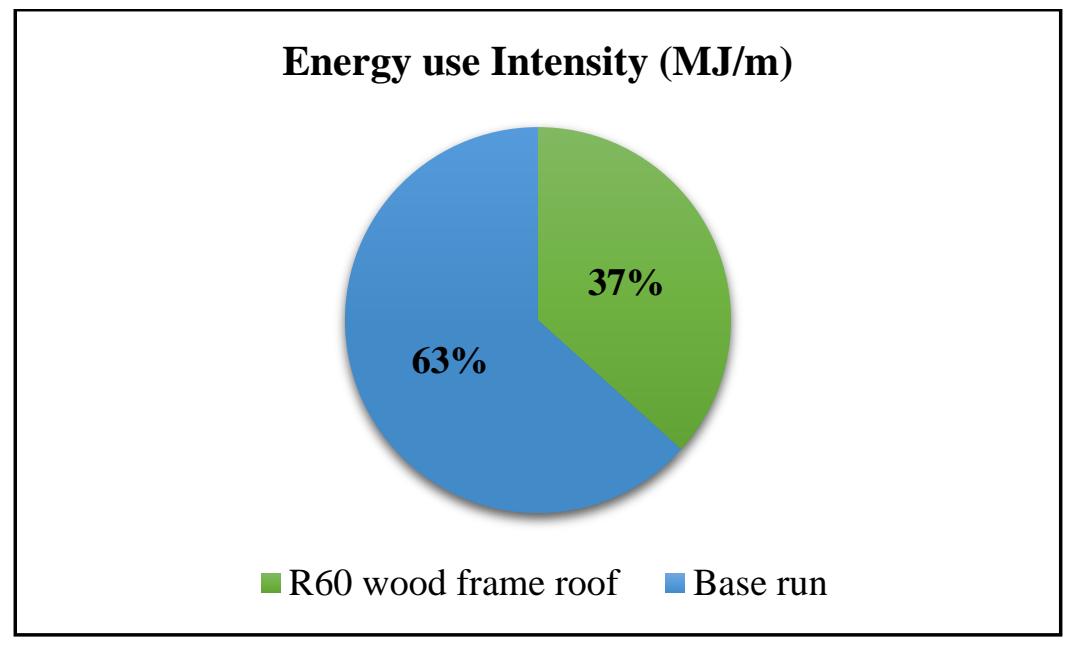

Figure 6 Comparison of Energy use Intensity

\section{ANNUAL ENERGY USAGE}

When alternative materials such as metal and wood were utilized to insulate, the annual energy cost was minimal. For the purposes of comparison, the R60 wood frame roof is chosen as the most energy-efficient roof option. Figure 7 shows a comparison of electric end usage and it can be shown that heating, ventilation and air conditioning can be lowered. 
Annual Electric End Use

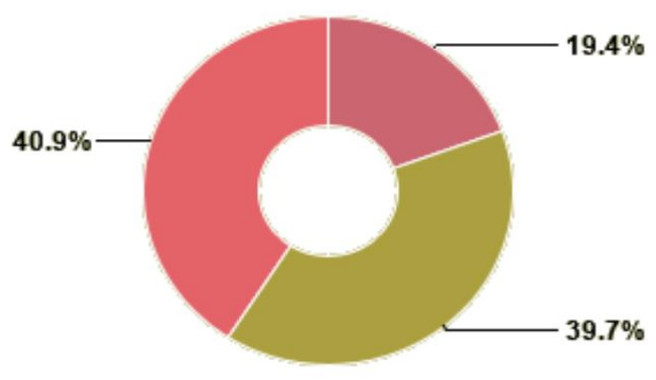

HVAC $19.4 \%$

Other $39.7 \%$

Lights $40.9 \%$

(a)
Annual Electric End Use

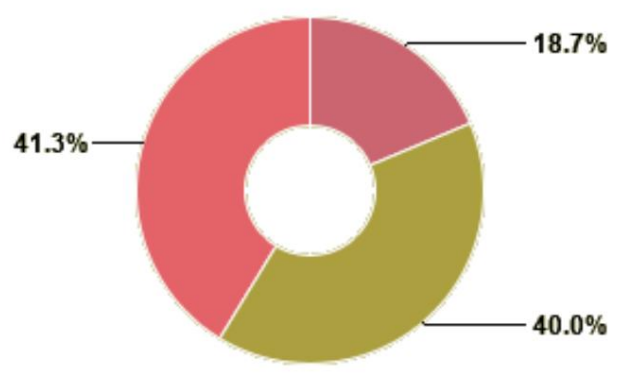

HVAC $18.7 \%$

Other $40.0 \%$

Lights $41.3 \%$

(b)

Figure 7 Annual Electric End use for a) base run and b) R60 wood frame roof

In a graphical format, additional breakdowns of expected energy use for annual fuel needs such as lighting, (heating, ventilation and air-conditioning) and space-heating are offered. Figure 8 shows a comparison of the base and alternate runs' annual fuel end usage.

Annual Fuel End Use

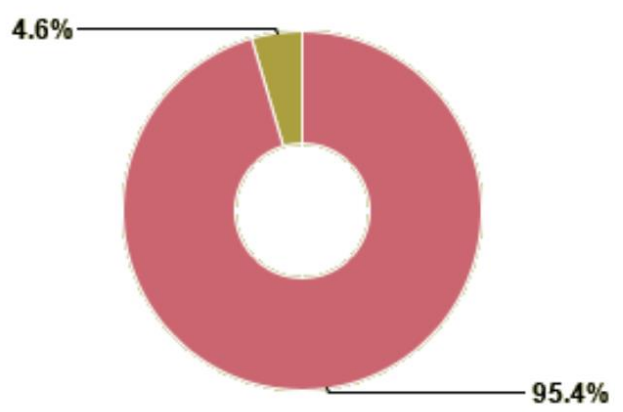

HVAC $95.4 \%$

Other $4.6 \%$
Annual Fuel End Use

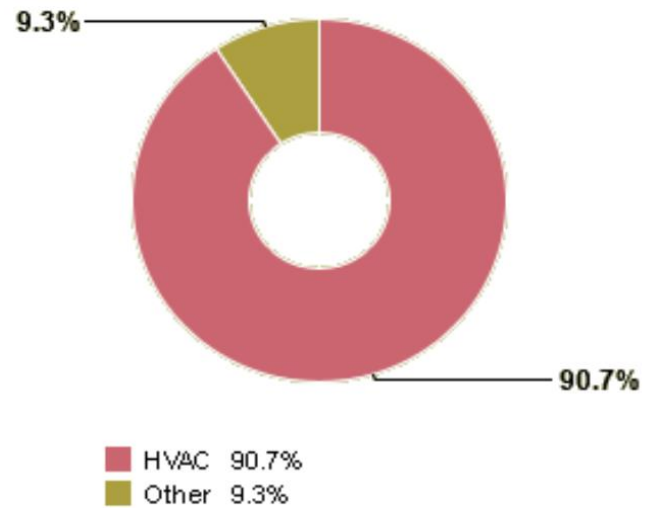

(b)

Figure 8 Annual fuel end use for a) base run and b) R60 wood frame roof

\section{CONCLUSION}

- By providing clear information about building performance and investigating BIM-based building energy modeling, the current study contributed to more energy efficient buildings.

- Engineers and owners will be aided in selecting material specifications to reduce energy consumption by building modeling and research of the building's performance at the early stages of construction and preconstruction. 
- When comparing the energy cost and carbon emission of a residential construction with the basic material, the decrease in energy and carbon in percentage is as indicated in figure 9.

a) Annual energy cost $=17.6 \%$

b) Life cycle cost $=17.5 \%$

c) Onsite Fuel $=50.7 \%$

d) Large SUV Equivalent $=50 \%$

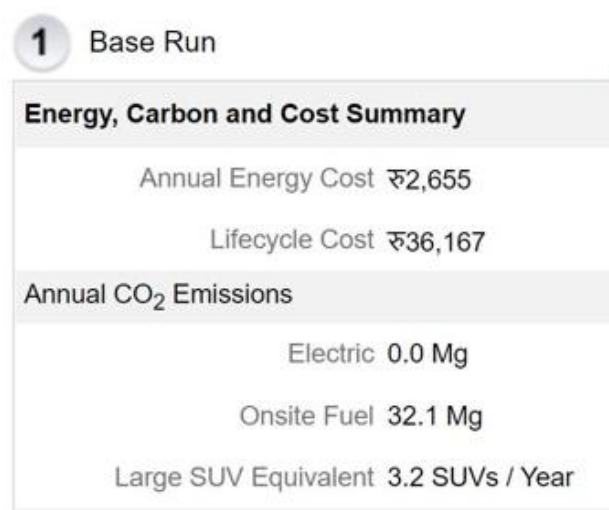

Figure 9 Comparison of the Energy, Carbon and Cost

\section{ACKNOWLEDGEMENT}

We would like to thank SRMIST for supporting us and the Department of civil engineering for giving us the privilege to present our paper.

\section{REFERENCES}

Agami Reddy, T. 2006. "Literature Review on Calibration of Building Energy Simulation Programs: Uses, Problems, Procedure, Uncertainty, and Tools.” ASHRAE Transactions 112 PART 1 (4844): 226-40.

Ashik Moulana, S., and S. Syed Abdul Rahman. 2017. "Control Strategies for Efficiency of Building." International Journal of Civil Engineering and Technology 8 (4): 703-10.

Balali, Amirhossein, Ali Hakimelahi, and Alireza Valipour. 2020. "Identification and Prioritization of Passive Energy Consumption Optimization Measures in the Building Industry: An Iranian Case Study." Journal of Building Engineering 30: 101239. https://doi.org/10.1016/j.jobe.2020.101239.

Banihashemi, Saeed, Grace K C Ding, and Jack Jianguo Wang. 2015. "Developing a Framework of Artificial Intelligence Application Cobra Aubea 2015,” no. July. 
Basack, Sumana, and Arup Sarkar. 2019. "Bim Framework for Operational Energy Assessment in Composite Clim `ate at Early Design Stage.” Building Engineer 94 (3): $22-27$.

Caldera, Matteo, Stefano Paolo Corgnati, and Marco Filippi. 2008. "Energy Demand for Space Heating through a Statistical Approach: Application to Residential Buildings.” Energy and Buildings 40 (10): 1972-83. https://doi.org/10.1016/j.enbuild.2008.05.005.

Catalina, Tiberiu, Joseph Virgone, and Eric Blanco. 2008. "Development and Validation of Regression Models to Predict Monthly Heating Demand for Residential Buildings." Energy and Buildings 40 (10): 1825-32. https://doi.org/10.1016/j.enbuild.2008.04.001.

Gerrish, Tristan, Kirti Ruikar, Malcolm Cook, Mark Johnson, Mark Phillip, and Christine Lowry. 2017. "BIM Application to Building Energy Performance Visualisation and ManagementChallenges and Potential." Energy and Buildings 144: 218-28. https://doi.org/10.1016/j.enbuild.2017.03.032.

Gong, Xinzhi, Chenyang Jia, Yilei Yu, and Chuancheng Li. 2019. "Optimization of Passive Design Measures for Residential Buildings in Chinese Hot Summer and Cold Winter Areas." IOP Conference Series: Earth and Environmental Science 310 (2): 2-8. https://doi.org/10.1088/1755-1315/310/2/022058.

Gracia, Alvaro De, and Luisa F. Cabeza. 2015. "Phase Change Materials and Thermal Energy Storage for Buildings." Energy and Buildings 103: 414-19. https://doi.org/10.1016/j.enbuild.2015.06.007.

Hamilton, Ian, Gesche Huebner, and Richard Griffiths. 2016. "Valuing Energy Performance in Home Purchasing: An Analysis of Mortgage Lending for Sustainable Buildings." Procedia Engineering 145: 319-26. https://doi.org/10.1016/j.proeng.2016.04.080.

Hedayati, A L I. 2016. "Bim-Based Energy Analysis of Conventional Residential Buildings in Hot-Humid Climate." International Journal of Advances in Mechanical and Civil Engineering 3 (3): 63-67.

Ji, Wenying, and Simaan M. AbouRizk. 2018. "Data-Driven Simulation Model for Quality-Induced Rework Cost Estimation and Control Using Absorbing Markov Chains." Journal of Construction Engineering and Management 144 (8): 04018078. https://doi.org/10.1061/(asce)co.1943-7862.0001534.

Luziani, Sarah, and Beta Paramita. 2019. “Autodesk Green Building Studio an Energy Simulation Analysis in the Design Process." KnE Social Sciences, no. August. https://doi.org/10.18502/kss.v3i21.5007. 
Migilinskas, Darius, Vladimir Popov, Virgaudas Juocevicius, and Leonas Ustinovichius. 2013. "The Benefits, Obstacles and Problems of Practical Bim Implementation." $\begin{array}{llll}\text { Procedia } & \text { Engineering } & 57 & \text { (May }\end{array}$ https://doi.org/10.1016/j.proeng.2013.04.097.

Norford, L. K., R. H. Socolow, E. S. Hsieh, and G. V. Spadaro. 1994. "Two-to-One Discrepancy between Measured and Predicted Performance of a 'low-Energy' Office Building: Insights from a Reconciliation Based on the DOE-2 Model." Energy and Buildings 21 (2): 121-31. https://doi.org/10.1016/0378-7788(94)90005-1.

Radziszewska-Zielina, Elżbieta. 2014. "A Comparative Analysis of Selected Parameters of Roofing Used in the Polish Construction Industry." Selected Scientific Papers - Journal of Civil Engineering 9 (1): 41-50. https://doi.org/10.2478/sspjce-2014-0005.

Santos, Rúben, António A. Costa, and António Grilo. 2017. "Bibliometric Analysis and Review of Building Information Modelling Literature Published between 2005 and 2015." Automation in Construction 80 (October): 118-36. https://doi.org/10.1016/j.autcon.2017.03.005.

Taleghani, Mohammad, Kamyar Tolou Behboud, and Shahin Heidari. 2010. "Energy Efficient Architectural Design Strategies in Hot-Dry Area of Iran: Kashan.” Emirates Journal for Engineering Research 15 (2): 85-91.

Toguyeni, David Y.K., Ousmane Coulibaly, Abdoulaye Ouedraogo, Jean Koulidiati, Yvan Dutil, and Daniel Rousse. 2012. "Study of the Influence of Roof Insulation Involving Local Materials on Cooling Loads of Houses Built of Clay and Straw." Energy and Buildings 50 (July): 74-80. https://doi.org/10.1016/j.enbuild.2012.03.021.

Venkataraman, Ashwin, and .M Ramesh Kannan. 2013. "Whole Building Energy Analysis Using BIM.” International Confrence of Advances in Civil Engineering, no. September.

https://www.researchgate.net/publication/281965883_Whole_Building_Energy_Analysi s_using_BIM.

Vogiatzi, Chrysa, Georgia Gemenetzi, Lina Massou, Stavros Poulopoulos, Spiros Papaefthimiou, and Efthimios Zervas. 2018. "Energy Use and Saving in Residential Sector and Occupant Behavior: A Case Study in Athens." Energy and Buildings 181: 19. https://doi.org/10.1016/j.enbuild.2018.09.039. 